\title{
ANALISIS STRATEGI PROMOSI DALAM PENGEMBANGAN PARIWISATA \\ (STUDI KASUS PADA PARIWISATA KABUPATEN PURWAKARTA)
}

\author{
Mia Rachmayanti ${ }^{1)}$, Nofha Rina ${ }^{2)}$ \\ 1) Program Studi Ilmu Komunikasi Universitas Telkom \\ ${ }^{2)}$ Program Studi Ilmu Komunikasi Universitas Telkom \\ Email ; ${ }^{1)}$ rachmayantimia@gmail.com, ${ }^{2)}$ nofharina80@gmail.com
}

\begin{abstract}
This research entitled "Analysis of Promotion Strategy as part of Tourism Development (Case Study of Tourism Purwakarta Regency)". The purpose of this research is to discover a descriptive explanation of promotion strategy that is applied in Purwakarta Regency in order to promote their tourism sector. This research has taken place at the five top destinations which are Taman Air Mancur Sribaduga, Waduk Jatiluhur, Taman Surawisesa, Makam Syech Baing Yusuf, and Taman Pancawarna. Researchers conducted interviews with the Department of Tourism, the Office of Education and Operations Manager Grama tirta Jatiluhur as the parties who manage these tourist destinations. The method used in the research is qualitative descriptive study. Researcher collects data from conducting interviews, also supported by literature review, documentations, and observations. The research study indicate that Purwakarta Regency had applied promotion strategy activities such as target audience identification, determining communication objectives, planning the messages for the audience, choosing the suitable media and the accurate message references, collecting feedbacks, and setting the total amount of promotional budget.
\end{abstract}

Keywords: Promotion strategy, Purwakarta Regency, tourism

\section{PENDAHULUAN}

Kabupaten Purwakarta merupakan

salah satu Kabupaten terkecil di Provinsi Jawa Barat, namun memilki potensi kemajuan daerah yang sangat pesat dengan dilihat dari letak secara geografis. Kabupaten Purwakarta berada pada jalur utama lalu lintas yang sangat strategis, yaitu jalur Jakarta, Purwakarta, Bandung dan Cirebon. Hal ini sangat mendukung Kabupaten Purwakarta menjadi kawasan pengembangan pariwisata karena letak yang strategis dan memiliki banyak potensi pariwisata yang menarik. Mulai dari wisata alam, wisata budaya, wisata religi hingga wisata buatan. Banyaknya objek wisata di Kabupaten Purwakarta di buktikan pula berdasarkan Surat Keputusan Bupati tahun 2015, dimana saat itu hanya terdaftar sebanyak 32 objek wisata namun pada tahun 2016 bertambah menjadi 47 objek wisata.

Kabupaten Purwakarta tidak mainmain dalam melakukan pengembangan di sektor pariwisata. Hal ini dibuktikan dengan dihadirkannya beberapa objek pariwisata yang berstandar internasional yaitu Taman Air Mancur Sribaduga, dimana air mancur ini merupakan air mancur terbesar di Asia tenggara. Museum Diorama atau Bale Panyawangan Diorama yang merupakan 
museum berbasis teknologi yang menggunakan sistem digital, dan berbagai destinasi wisata alam unggulan yang menawarkan beragam panorama menarik. Berdasarkan data tersebut menunjukan bahwa Kabupaten Purwakarta sangat layak dijadikan sebagai salah satu Kabupaten yang memiliki andil besar dalam memajukan pariwisata baik dalam Provinsi Jawa Barat maupun Indonesia bukan hanya kaya akan tempat wisata namun juga kaya akan kebudayaan yang berada di dalam masyarakatnya. Hal ini tentunya sejalan dengan progam Visi Misi Kabupaten Purwakarta dalam strategi dan arah kebijakan pembangunan.

Berdasarkan data objek dan daya tarik wisata yang tahun 2014-2016 terdapat perbedaan jumlah kunjungan wisatawan pada tahun 2014 tidak jauh berbeda dengan tahun 2015 namun yang menjadi menarik di tahun 2016 peningkatan terjadi hampir $100 \%$ dari tahun sebelumnya dan juga objek wisata yang dikunjungi wisatawan pun semakin banyak jumlahnya, hal ini tentunya merupakan suatu perkembangan yang baik hanya saja apabila di bandingkan dengan Surat Keputusan Objek Wisata oleh Bupati Purwakarta tahun 2016, jumlah objek wisata yang dikunjungi pada tahun 2016 hanya 29 objek wisata dari 47 objek wisata yang di tetapkan oleh Bupati Purwakarta. Dapat disimpulkan bahwa Kabupaten Purwakarta membutuhkan strategi pemasaran yang tepat untuk mengembangkan pariwisata di daerah ini terutama dalam startegi promosi. Promosi pariwisata yang ada di kabupaten ini dinilai cukup menarik karena dalam waktu yang cukup singkat dapat meningkatkan jumlah wisatawan hampir seratus persen. Tentunya Kabupaten Purwakarta masih memiliki kekurangan karena kurangnya pembaruan mengenai informasi pariwisatanya sehingga masih banyak objek wisata yang belum diketahui dan dikunjungi oleh wisatawan, sedangkan jumlah kunjungan wisatawan baik lokal maupun domestik mengalami kenaikan setiap tahunnya.

Menurut Kotler dan Armstrong (2008:123) dalam mengembangkan program komunikasi dan promosi terintegrasi yang efektif pemasar harus melakukan hal-hal berikut: Mengidentifikasi pemirsa sasaran, menentukan tujuan komunikasi, merancang pesan, memilih media untuk mengirimkan pesan, memilih sumber pesan, dan mengumpulkan umpan balik.

Strategi promosi sangat berperan penting untuk bisa membantu pariwisata Kabupaten Purwakarta agar lebih dikenal tidak hanya oleh masyarakat Purwakarta, tetapi juga masyarakat luar yang memiliki potensi yang sama untuk berkunjung ke destinasi wisata Kabupaten Purwakarta. Selain dari strategi promosi tentunya peran pemerintah daerah lah yang utama. Pemerintah daerah yang memiliki kewenangan untuk merencanakan pembangunan pariwisata hingga melakukan 
perencanaan promosi objek wisata yang ada khususnya di Kabupaten Purwakarta agar sejalan dengan visi misi Kabupaten Purwakarta.

\section{TINJAUAN PUSTAKA}

\section{Promosi}

Bukhari Alma berpendapat dalam Ratih (2005:57) “ promosi merupakan bagian dari komunikasi pemasaran, maksudnya dalam komunikasi pemasaran juga terdapat aktivitasaktivitas promosi yang memiliki tujuan untuk menyampaikan informasi, mempengaruhi target sasaran dan juga sebagai pengingat kepada target sasaran, agar target sasaran memiliki loyalitas terhadap produk atau jasa yang ditawarkan oleh perusahaan". Menurut Alfred Chandler dalam Ismail Solihin (2012:25) "strategi adalah penentuan sasaran dan penentuan jangka panjang dari suatu perusahaan serta pengadopsian seperangkat tindakan serta alokasi sumber daya yang diperlukan untuk melaksanakan tujuan tersebut. maka dari itu strategi adalah penentu keberhasilan suatu tujuan dan harus di rencanakan secara matang dan terstruktur".

Sedangkan strategi menurut Zaki dan Priyo (2015:14) adalah "pola pengaturan kebijakan dan rencana untuk mencapai tujuan yang diinginkan". Maka dari itu strategi promosi dapat di artikan sebagai suatu perencanaan atau pola yang diatur dan direncanakan untuk menyampaikan suatu informasi mengenai suatu produk atau jasa kepada target sasaran.

\section{Strategi Promosi}

Strategi promosi menurut Kotler dan Armstrong (2001:74) adalah "kreativitas mengkomunikasikan keunggulan produk serta membujuk pasar sasaran". Ada beberapa hal yang perlu diperhatikan dalam mengembangkan promosi terintegrasi untuk mencapai strategi promosi yang efektif, antara lain (Kotler dan Armstrong,2008 : 123- 132).

1. Mengidentifikasi Pemirsa Sasaran (berhubungan dengan segmentasi pasarnya). Target audience bisa merupakan individu, kelompok masyarakat khusus atau umum (Ratnasari dan Aksa, 2011: 83).

2. Tentukan tujuan promosi. Pemasar harus memutuskan respon apa yang mereka cari, umumnya adalah respon pembelian.

3. Merancang Pesan, Ini berhubungan dengan isi pesan struktur pesan, dan format pesan (Kotler dan Armstrong, 2008: 125-127).

4. Memilih Media. Terdapat dua jenis saluran, yakni saluran komunikasi pribadi (personal communication channel) dan saluran komunikasi nonpribadi (nonpersonal communication channel) (Kotler dan Armstrong, 2008: 128-130).

5. Memilih Sumber Pesan. Menurut Mahmud Machfoedz (2010: 8), pesan yang disampaikan oleh sumber yang dapat dipercaya akan bersifat lebih persuasif. 
Ada tiga faktor yang menjadikan sumber pesan dipercaya, antara lain ahli, dapat dipercaya, dan disukai.

6. Mengupulkan Umpan Balik. Umpan balik komunikasi pemasaran mungkin menyarankan perubahan dalam program promosi atau dalam penawaran produk itu sendiri (Kotler dan Armstrong, 2008: 131).

7. Menetapkan Total Anggaran Promosi. Ada empat metode umum yang digunakan untuk menetapkan anggaran promosi, antara lain metode terjangkau (affordable method), metode persentase penjualan (percentage-of-sales method), metode paritas kompetitif (competitive-parity method), dan metode tujuan dan tugas (objective and task method) (Kotler dan Armstrong, 2008: 134).

\section{Pariwisata}

Kuntowijoyo (dalam Wardiyanta, 2006:49) menyatakan pariwisata memiliki dua pandangan makna yaitu dilihat dari aspek kelembagaan dan aspek substansial, yaitu "jika dilihat dari sisi kelembagaan, pariwisata adalah lembaga yang dibentuk sebagai usaha manusia untuk memenuhi kebutuhan rekreatifnya sedangkan sebagai sebuah substansi, pariwisata tidak dapat dipisahkan dengan budaya dari suatu masyarakat, dimana hal itu berkaitan dengan cara penggunaan waktu senggang yang dimiliki oleh tiap-tiap masyarakatnya".

\section{METODOLOGI PENELITIAN}

Penelitian ini menggunakan paradigma konstruktivisme karena dalam pengertian paradigma ini berpendapat bahwa pembentukan suatu makna dalam suatu objek dibentuk karena adanya beberapa konstruksi sosial. Sehinggga dalam paradigma ini manusia tidak bisa hanya melihat dari satu sisi konstruksi sosial saja.

Paradigma sendiri memiliki makna cara pandang yang didasari oleh nilai-nilai tertentu dan berisikan teori pokok, konsepsi, asusmi, atau cara pendekatan yang dapat digunakan oleh para teoritisi dan praktisi dalam memecahkan suatu permasalahan, menurut Mustopadidjaja (2000) dalam Djam'an dan Aan (2012:9).

Ardianto dan Anees (2007:151-152) berpendapat bahwa Konstruktivisme secara epistimologis merupakan "hasil konstruksi sosial, dimana pengetahuan manusia merupakan konstruksi yang dibangun dari proses kognitif dengan interaksinya dengan dunia objek material".

Ardianto dan Anees,

$(2007: 158)$

menyatakan bahwa konstruktivisme dalam ilmu komunikasi lebih kepada penelitian kumunikasi anterpersonal. Robyn Penmann menyampaikan kaitan konstruktivisme dengan ilmu komunikasi dalam (Ardianto dan Anees, 2007:158) :

1. Tindakan komunikatif yang sifatnya sukarela, dalam hal ini yang dimaksud 
adalah siapapun pelaku komunikasi bebas memilih subjeknya meskipun dibatasi oleh lingkungan sosialnya.

2. Pengetahuan adalah sebuah produk sosial, dalam hal ini konstruktivisme meyakini pengetahuan bukan berasal dari suatu yang objektif melainkan terbentuk dari interaksi dalam kelompok sosial.

3. Pengetahuan yang bersifat kontekstual, maksudnya pengetahuan merupakan sesuatu yang tidak bertahan lama seiring dengan perkembangan zaman.

4. Teori-teori menciptakan dunia. Teori bukan dianggap sebagai alat melainkan suatu cara pandang yang ikut memengaruhi pada cara pandang kita terhadap realitas atau dalam batas tertentu teori menciptakan dunia.

5. Pengetahuan bersifat sarat nilai.

Dalam penelitian ini paradigma konstruktivisme di gunakan karena dalam pembentukan strategi promosi perkembangan pariwisata suatu daerah tidak hanya bisa dibangun atau direncanakan berdasarkan latarbelakang satu objek tertentu saja, melainkan harus juga di selaraskan atau di bentuk dari beberapa konstruksi misalnya, bagaimana perkembangan perekonomian masayarakat, perkembangan pembangunan infrastruktur serta perkembangan sektor pendidikan masyarakatnya.

Penelitian ini termasuk kedalam penelitian kualitatif karena dalam penelitian ini menggunakan fenomena-fenomena sosial yang terus berkembang sehingga sulit apabila dikuantifikasikan. Penelitian Kualitatif adalah penelitian yang menggunakan latar alamiah, dengan maksud mengartikan peristiwaperistiwa yang terjadi Menurut Denzin dan Lincoln (Moelong, 2007:5) dalam buku metode penelitian kualitatif (Djam'an Satori dan Aan Komariah (2009:23).

Menurut Bogdan dan Biklen (1982) berpendapat dalam Sugiyono (2005: 9-10 ) Karakteristik penelitian kualitatif adalah sebagai berikut :

1. Dilakukan pada kondisi yang alamiah, langsung ke sumber data dan peneliti berkedudukan sebagai instrumen kunci.

2. Penelitian kualitatif bersifat deskriptif, yaitu penjabaran data yang berbentuk katakata atau gambar, dan tidak menekankan pada angka

3. Penelitian kualitatif lebih menekankan pada proses dari pada produk atau outcome

4. Penelitian kualitatif melakukan analisis data secara induktif

5. Penelitian kualitatif lebih menekankan pada makna (data dibalik yang teramati)

Pendekatan yang dilakukan dalam penelitian ini adalah studi kasus .deskriptif Menurut Robert K.Yin (2002:1), secara umum studi kasus adalah "strategi yang lebih ideal karena memiliki acuan pokok pertanyaan berkaitan dengan "how" atau "why", sehingga peneliti hanya memiliki sedikit kesempatan 
untuk mengendalikan peristiwa-peristiwa yang akan diteliti dan fokus penelitiannya pun terletak pada fenomena terkini dalam kehidupan sosial".

Adapun Basuki (2006:113) mengatakan bahwa studi kasus merupakan "kajian mendalam tentang peristiwa, lingkungan dan situasi tertentu yang memungkinkan mengungkapkan atau memahami sesuatu hal" (dalam Prastowo, 2011:127-129).

Sedangkan penelitian deskriptif adalah "pencarian fakta dengan interpretasi yang tepat, dalam penelitian ini mempelajari masalah di dalam lingkungan sosial seperti dalam elemen masyarakat, situasi sosial, kegiatan sosial, sikap sosial, pandanganpandangan serta proses dan pengaruh dari suatu peristiwa" menurut Whitney (1960) dalam Moh, Nazir (2005:54-55).

\section{HASIL DAN PEMBAHASAN}

Strategi promosi dalam sektor pariwisata penting dilakukan karena sektor pariwisata merupakan industri yang terus berkembang pesat dan persaingan akan semakin ketat, sehingga strategi promosi pariwisata memiliki peran yang sangat besar. Ada beberapa hal yang perlu diperhatikan dalam mengembangkan promosi terintegrasi untuk mencapai strategi promosi yang efektif, antara lain mengidentifikasi pemirsa sasaran, menentukan tujuan promosi, merancang pesan, memilih media, memilih sumber pesan, menetapkan total anggaran promosi (Kotler dan Armstrong,2008 : 123- 132). Berikut pebahasan dari setiap langkah-langkah yang dilakukan oleh Kabupaten Purwakarta:

1. Mengidentifikasi Pemirsa Sasaran

Target sasaran akan sangat mempengaruhi keputusan pemasar untuk menentukan tentang apa yang akan dilakukan, bagaimana pesan itu disampaikan, dimana pesan itu dikatakan, dan siapa yang mengatakannya (Kotler dan Armstrong,2008 : 124). Kabupaten Purwakarta dalam hal ini berupaya untuk menentukan target sasaran promosi yaitu masyarakat Purwakarta, namun seiring berjalannya waktu pariwisata Kabupaten Purwakarta mulai banyak di kenal oleh masyarakat luar Purwakarta karena banyaknya liputan-liputan seputar pariwisata Kabupaten Purwakarta dan juga adanya peran media sosial, dalam hal ini berbeda dengan wisata religi dan juga waduk Jatiluhur yang sudah lebih dulu menargetkan masyarakat luar Purwakarta karena wisata ini sudah jauh lebih terkenal di bandingkan dengan wisata lain di Kabupaten Purwakarta. Hal ini sesuai dengan teori yang menjelaskan bahwa target sasaran terbagi menjadi dua yaitu publik intern dan juga publik ekstern menurut Effendy (1992:10). Berikut adalah sasaran promosi, yaitu:
a) Publik intern

Seluruh khalayak yang berkaitan langsung dengan organisasi tersebut seperti pegawai dan 
para pemegang saham dan serikat kerja. Dalam hal ini Publik internal yang dimaksud dalam target promosi Kabupaten Purwakarta adalah masyarakat lokal atau penduduk Kabupaten Purwakarta.

b) Publik ekstern

Seluruh khalayak yang tidak berkaitan langsung oleh suatu organisasi namun berperan dalam kegiatan organiasasi. Dalam hal ini publik eksternal yang dimaksud adalah masyarakat diluar Kabupaten Purwakarta yang memiliki potensi yang sama sebagai pengunjung wisata.

Identifikasi sasaran yang dilakukan oleh dinas pariwisata dengan cara menyampaikan dalam setiap kegiatan rapat mingguan di kecamatan-kecamatan mengenai rencana menjadikan Kabupaten Purwakarta menjadi Kabupaten Pariwisata serta membentuk jaringan komunikasi antara pemerintah dengan masyarakat pecinta pariwisata di Purwakarta, pemerintah dengan group-group di media sosial, pemerintah dengan anak-anak SMA, serta pemerintah dengan Mahasiswa di perguruan tinggi Purwakarta. Dinas Pendidikan memiliki cara tersendiri untuk mengidentifikasi target sasarannya yaitu para siswa di Kabuapeten Purwakarta, dengan cara menyampaikan pesan kepada MKKS (Musyawarah Kerja Kepala Sekolah) untuk menghadirkan siswanya di setiap minggu dalam kegiatan pemutaran film di Taman Surawisesa. Namun sedikit berbeda dengan yang dilakukan oleh pengelola Waduk Jatiluhur yaitu dengan melakukan pendataan di buku tamu setiap setiap minggunya.

2. Tujuan Komunikasi

Tujuan komunikasi sama halnya dengan tujuan promosi yang ingin disampaikan oleh Kabupaten Purwakarta. Setiap kegiatan pasti memiliki tujuan sama dengan promosi yang memiliki tujuan pada tiap-tiap target sasarannya. Harman Malau dalam bukunya manajemen pemasaran (2017:112-113) berpendapat bahwa ada beberapa tujuan dari promosi yaitu menginformasikan, mempengaruhi, dan membujuk serta mengingatkan target sasaran mengenai perusahaan dan bauran pemasarannya. Dinas pendidikan telah memenuhi keseluruhan tujuan komunikasi yaitu untuk menginformasikan, mempengaruhi serta mengingatkan dengan cara mengatur konten untuk pesan promosi yang dilakukan setiap minggunya, seperti pada hari senin, selasa, rabu, dijabarkan jenis-jenis destinasi wisata di kabupaten Purwakarta, pada hari sabtu, minggu mulai diingatkan kembali objek wisata apa saja yang kiranya bisa dikunjungi saat akhir pekan. Tujuan komunikasi yang telah disampaikan diharapkan dapat diterima oleh target sasaran yang dituju, namun ada sedikit perbedaan yang dilakukan oleh Dinas Pendidikan dalam melakukan kegiatan promosi Taman Surawisesa karena dalam hal ini pesan yang disampaikan oleh Dinas 
Pendidikan seputar Taman Surwisesa hanya berupa pesan melalui aplikasi Whatsapp kepada MKKS (Musyawarah Kerja Kepala Sekolah) yang bertujuan menginformasikan saja tidak mencakup tujuan pesan untuk mempengaruhi para pengunjung. Karena adanya sistem ajakan Dinas Pendidikan kepada masing-masing sekolah untuk wajib menghadirkan muridnya dalam kegiatan pemutaran film edukasi, maka ada indikasi bahwa hadirnya siswa bukan berdasarkan minat pribadi yang dipengaruhi dari ketertarikannya dengan Taman Surwisesa dan juga jenis film yang diputar, selanjutnya pengelola Waduk Jatiluhur juga telah mencakup tujuan komunikasi yaitu dengan cara melakukan publikasi di media sosial dengan konten-konten yang bertujuan menginformasikan, mengingatkan serta mempengaruhi target sasaran.

3. Merancang pesan

Setelah mendefinisikan respons pemirsa yang diinginkan, pemasar mengembangkan pesan yang efektif. Idealnya pesan harus mendapat Perhatian (Attention), mempertahankan Minat (Interest), membangkitkan Hasrat (Desire), dan meraih Tindakan (Action) (kerangka kerja yang dikenal sebagai model AIDA). Hal Ini berhubungan dengan isi pesan struktur pesan, dan format pesan, menurut Kotler dan Armstrong (2008:125).
Pesan yang ingin disampaikan kepada target sasaran harus diatur secara matang mulai dari isi pesan, struktur pesan dan yang terakhir format pesan. Kabupaten Purwakarta dalam hal ini sudah merancang pesan secara baik dimulai dari pengaturan isi pesan yang baik. Isi pesan sendiri memiliki tiga tema yaitu tema rasional, tema emosional dan yang terakhir tema moral. Berdasarkan hasil penelitian selama dilapangan pesan yang disampaikan oleh Dinas Pariwisata berupa tema rasional, tema emosional dan juga tema moral. Tema rasional dengan menjelaskan keunggulan dari masing-msing objek wisata dalam setiap pesan promosi. Tema emosional dengan melihat respon dari para pengunjung setelah berkunjung ke setiap objek wisata. Tema moral dengan menyampaikan pesanpesan seperti jangan membuang sampah sembarangan.

Dinas Pendidikan dalam hal ini hanya menerapkan dua tema secara lebih dominan yaitu Tema rasional yang terapkan dinas pendidikan dengan menyampaikan fasilitasfasilitas yang tersedia di Taman Surawisesa,seperti adanya teropong bintang dan tema moral dengan memutarkan film edukasi serta menyelingi informasi mengenai objek-objek wisata yang ada di kabupaten Purwakarta sebelum dan sesudah penayangan film. Pengelola Waduk Jatiluhur juga menerapkan ketiga tema yaitu, tema rasional diterapkan dengan menonjolkan keunggulan 
waduk Jatiluhur dimana jatilihur merupakan bendungan terbesar di Indonesia dan juga bendungan serbaguna pertama di Indonesa, serta menawarkan pemandangan yang indah. Tema emosional diterapkan dengan melihat respon pengunjung yang datang serta tema moral di sampaikan dengan melakukan selingan pesan seperti jangan membuang sampah sembarangan pada penyampaian pesan promosi. Tema rasional memiliki dominasi yang lebih tinggi dimana pesan rasional menampilkan keunggulan-keunggulan dari masing-masing objek wisata sehingga dapat membantu menarik minat target wisatawan untuk berkunjung ke Purwakarta. Namun, ada dua tema yang belum diterapkan secara terencana oleh Kabupaten Purwakarta dalam isi pesan yang disampaikan yaitu tema emosional dan moral.

Tema emosional yang disampaikan bisa dikatakan tidak secara langsung disampaikan hanya saja para pengelola objek wisata melihat bagaimana respon pengunjung setelah mengunjungi objek pariwisata Kabupaten Purwakarta, kedua tema moral, tema ini sebenarnya belum dijadikan inti pokok dari penyampaian pesan promosi hanya saja sebagai selingan atau tambahan dalam setiap penyampaian pesan promosi Kabupaten Purwakarta, hal ini dibuktikan dengan belum adanya pesan moral seperti campaign tertentu yang berkaitan dengan pariwisata Kabupaten Purwakarta. Hal ini cukup disayagkan karena apabila kedua tema tersebut diterapkan dengan baik dan terencana dapat menambah variasi bentuk pesan sehingga dapat lebih menarik minat pengunjung.

Struktur pesan yang digunakan dalam pesan promosi Kabupaten Purwakarta menunjukan bahwa Kabupaten Purwakarta membuat kesan yang kuat terlebih dahulu barulah disampaikan kepada masyarakat, sehingga informasi yang disampaikan dapat diterima dengan makna yang sama dan juga mudah dipahami oleh target sasaran sehingga tidak menyebabkan kesalahpahaman dalam penyampaian pesan.

Format pesan yang disampaikan oleh Dinas Pariwisata sudah sesuai dengan judul, tema, teks ilustrasi serta warna yang sesuai dengan objek wisata yang dipromosikan Karena sebelum cetak atau dipublikasikan, seluruh informasi akan di lakukan pengecekan terlebih dahulu dari Dinas Pariwisata. Format pesan yang digunakan oleh Dinas Pariwisata yaitu Menyampaikan kalimat awal "sampurasun" pada setiap penyampaian pesan, penempatan logo Purwakarta pada penyampaian pesan, serta foto dari masingmasing objek wisata yang akan di publikasikan.

Format pesan yang disampaikan oleh Dinas pendidikan hanya menyesuaikan dengan teks saja karena Dinas Pariwisata menyampaikan pesan melalui aplikasi whatsapp untuk meminta MKKS 
(Musyawarah Kerja Kepala Sekolah) menghadirkan siswanya agar datang ke Taman Surawisesa dalam kegiatan pemutaran film edukasi.

Pengelola Waduk Jatiluhur juga menggunakan format pesan yang sudah sesuai dengan tema, teks, ilustrasi serta judul yang sesuai dengan cara dengan menampilkan foto objek wisata yang dipromosikan. Dapat disimpulkan bahwa Format pesan yang disampaikan oleh Kabupaten Purwakarta yang melalui media cetak, media sosial, media online, media reklame, serta media penyiaran pun juga sudah sesuai dengan judul, tema, teks, ilustrasi serta warna yang digunakan. Hanya saja terdapat sedikit perbedaan dengan Taman Surawisesa dimana penyampaian pesan nya melalui aplikasi Whatsapp dan ditujukan untuk kepala sekolah tiap tiap sekolah di Kabupaten Purwakarta, pesannya pun hanya menginformasikan untuk siswa di setiap perwakilan sekolah hadir dalam kegiatan pemutaran film di Taman Surawisesa, sehingga untuk tema, ilustrasi, warna tidak dipikirkan begitu matang, hanya teks nya saja yang memang sudah sesuai.

\section{Memilih Media}

Pemilihan media dalam melakukan strategi sama saja dengan ujung tombak dari keberhasilan strategi promosi. Memilih media terbagi menjadi dua bagian yaitu Saluran Komunikasi Pribadi adalah dua atau lebih orang berkomunikasi secara langsung satu sama lain. Mereka bisa berkomunikasi melalui tatap muka, telepon, melalui pos atau email, atau bahkan melalui "percakapan" internet dan saluran komunikasi non pribadi adalah media yang membawa pesan tanpa hubungan pribadi atau umpan-balik. Saluran ini meliputi media utama, suasana, dan acara (Kotler dan Armstrong, 2008 : 128-129). Saluran komunikasi pribadi meliputi dua penyampaian pesan yaitu word of mouth dan buzz marketing.

Promosi melalui mulut ke mulut pada dasarnya bukan merupakan strategi promosi langsung dari Kabupaten Purwakarta. Namun, bentuk promosi ini tidak dipungkiri memiliki andil dalam peyebaran informasi mengenai destinasi wisata di Kabupaten Purwakarta. Terlebih lagi letak geografis yang berada di wilayah suburban dan kondisi sosial budaya masyarakat sekitar yang memiliki kecenderungan menyebarkan informasi satu sama lainnya menggunakan sarana komunikasi langsung. Hal ini menyebabkan word of mouth menjadi sarana promosi yang cukup efektif terutama pada lingkup masyarakat sekitar.

Berdasarkan hasil penelitian yang diperoleh, promosi melalui saluran komunikasi ini meliputi komunikasi tatap muka, word of mouth. Komunikasi tatap muka terjadi antara pengurus objek wisata dengan berbagai pihak, mulai dari masyarakat setempat, pengunjung, pejabat pemerintahan, maupun mitra kerjasamanya. Berbagai informasi yang beredar dengan pihak-pihak ini tak jarang 
disampaikan kembali pada pihak ketiga yang terus terjadi secara berantai hingga akhirnya menjadi word of mouth. Maka dari itu strategi ini bisa dilihat dari sisi para pengunjung mengenai informasi destinasi yang dkunjungi.

Seperti yang telah diketahui word of mouth marketing adalah "komunikasi personal mengenai sebuah produk, yang dilakukan antara target sasaran dan tetangga, temanteman, anggota keluarga serta rekan-rekan terdekat lainnya" (Kotler dan Armstrong, 2008:128).

Pemasaran dengan menggunakan konsep word of mouth sangat memiliki dampak yang sangat besar bagi para konsumen karena konsumen menganggap informasi yang disampaikan orang terdekat merupakan informasi yang objektif dan dapat dipercaya.

Buzz marketing juga sempat dilakukan oleh pihak Dinas Pariwisata Kabupaten Purwakarta dengan melempar sebuah isu mengenai objek wisata kampung monyet namun hal ini lebih kepada kegiatan pra riset yang dilakukan sebelum penentuan objek wisata kampung monyet sehingga Dinas Pariwisata mendapat respon dari masyarakat tentang rencara pembukaan wisata kampung monyet.

Saluran komunikasi non pribadi adalah saluran media yang membawa pesan tanpa hubungan pribadi atau umpan-balik saluran ini meliputi media utama, suasana dan acara. Media utama meliputi media cetak, media penyiaran, media reklame dan media online.
Dinas Pariwisata menggunakan media cetak yaitu majalah jelajah nusa, leaflet, booklet, tourism map. Media sosial yaitu twitter, facebook, instagram. Untuk surat kabar menggunakan sistem liputan yang nantinya akan dikemas dalam bentuk advertorial dimana liputan mulanya bersifat undangan namun karena semakin banyak terekspose akhirnya banyak media-media surat kabar yang juga tertarik untuk datang berkunjung tanpa diundang. Media online yaitu website Amazing Purwakarta dan bekerja sama dengan media online swasta yaitu detik dan juga tribun. Media penyiaran lokal Purwakarta yaitu radio pro $89 \mathrm{fm}$, galuh pakuan $\mathrm{Tv}$ dan juga Purwakarta Tv. Media penyiaran televisi lokal dilakukan dengan bekerja sama dengan dinas kominfo, dalam hal ini Dinas Pariwisata lebih fokus terhadap media sosial sebagai media promosi dengan membuat tim IT khusus yang tugasnya menyebarkan informasiinformasi kepada masyarakat, group-group (Group pecinta alam, group Mojang Jajaka, serta group siswa SMA) di media sosial, membuat caption, video serta melakukan upload foto di media sosial Dinas Pariwisata.

Dinas Pendidikan hanya menggunakan media sosial Whatsapp untuk menyampaikan pesan. Penyampaian pesan melalui mediamedia yang lain belum di terapkan mengingat penyerahan tanggung jawab pengelolaan Taman Surawisesa dari Dinas Pariwisata baru berjalan selama 3 bulan. 
Pengelola Waduk Jatiluhur menggunakan media untuk melakukan promosi yaitu media sosial dan media penyiaran dilakukan hanya saja bersifat liputan, media sosial yang digunakan oleh pengelola yaitu facebook dan juga instagram serta media penyiaran oleh TV swasta dilakukan dengan sistem liputan, pengelola hanya menyediakan lokasi sebagai tempat liputan.

Kesimpulannya dari media yang digunakan oleh Kabupaten Purwakarta dalam hal ini memiliki kekurangan yaitu penggunaan media reklame yang digunakan apabila sedang ada suatu event yang akan di gelar. pengelola wisata Waduk Jatiluhur yang hanya memfokuskan media sosial sebagai media yang efektif untuk melalukan suatu kegiatan promosi, karena menganggap media cetak sudah mulai ditinggalkan oleh pembacanya dan juga media penyiaran yang cukup memakan biaya, hanya saja untuk kerja sama peliputan masih bisa dilakukan karena menghemat pengeluaran promosi. Dinas Pendidikan sejauh ini belum memaksimalkan saluran komunikasi non pribadi yang dimiliki karena mengingat penyerahan pengelolaan yang baru dilimpahkan dari Dinas Pariwisata ke Dinas Pendidikan sehingga peranan Dinas Pariwisata masih dominan dalam melakukan strategi promosi Taman Surawisesa. Suasana yang di tampilkan oleh Dinas Pariwisata dalam setiap objek wisata di Kabupaten Purwakarta adalah suasana alam pedesaan dengan kekentalan budaya sunda didalamnya serta pemandangan yang indah mengingat Purwakarta yang berada diantara Gunung Burangrang dan Gunung Parang. Suasana ini dapat dirasakan dengan adanya Gapura Indung Rahayu pada saat memasuki seluruh wilayah Purwakarta, adaya sentuhan dekorasi pagar melati disetiap sudut bangunan wisata serta bangunan-bangunan di Purwakarta yang berbentuk julangapa. Dinas Pendidikan dalam hal ini berkaitan dengan pengelolaan Taman Surawisesa berusaha menampilkan suasana berbasis edukasi dengan berusaha menyediakan fasilitas edukasi seperti teropong bintang untuk digunakan para siswa. Pengelola Waduk Jatiluhur juga berusaha menampilkan suasana yang berbeda yaitu suasana yang nyaman dengan menawarkan spot-spot pemandangan pegunungan dan waduk jatiluhur, menyediakan wisata-wisata kuliner, serta menawarkan penginapan untuk para pengunjung.

Event atau acara apapun yang diselenggrarakan sebenarnya dapat menarik minat pengunjung wisata, tergantung bagaimana kita mengelolanya. Kabupaten Purwakarta melalui Dinas Pariwisata cukup memiliki beragam acara diantaranya Festival Seni Bela Diri Dunia, World Wide Instameet, Hari Jadi Purwakarta, Teplak Kuliner. Pengelola Waduk Jatiluhur juga mengadakan event yang sifatnya bekerjasama dengan beberapa sponsor, namun dalam hal ini 
pengelola Waduk Jatilihur juga menerima event wedding yang dianggap sebagai ajang promosi gratis. Penyelenggaraan event dengan bekerja sama dengan pihak ketiga tentunya memiliki keuntungan tersendiri yaitu menghemat anggaran penyelenggaraan event dan juga dapat menambah massa yang datang ke wisata Waduk Jatiluhur apabila kerja sama juga dilakukan dengan suatu komunitas yang memang memiliki massa yang cukup banyak.

Dinas Pendidikan dalam hal penyelenggaraan event di Taman Surawisesa belum bisa terlaksana selain pemutaran film edukasi mengingat penyerahan tanggung jawab ke Dinas Pendidikan baru berjalan 3 bulan, namun sudah mulai direncanakan untuk mengadakan suatu kegiatan di tahun 2018 yaitu festival film indie untuk diikuti oleh para siswa-siswi Purwakarta.

5. Memilih Sumber Pesan

Kabupaten Purwakarta juga memikirkan sumber pesan yang digunakan untuk menyebarkan informasi, secara dominan Dinas Pariwisata dan Dinas Pendidikan selaku pengelola objek wisata menjadikan Bupati Dedi Mulyadi sebagai sosok opinion leader yang dianggap dapat dijadikan sumber penyampaian pesan sehingga menarik minat banyak pengunjung. Kekuatan sosok pemimpin birokrasi di Kabupaten Purwakarta sangat dominan karena hampir seluruh masyarakatnya mengagumi sosok Bupati Purwakarta Dedi Mulyadi. Namun tidak sampai disitu waduk jatiluhur dirasa tidak memerlukan sosok seseorang dalam menyampaikan pesan karena dianggap sudah cukup terkenal padahal apabila hal ini disadari Waduk Jatiluhur akan menjadi objek wisata yang lebih dikenal dengan bantuan sosok opinion leader maka tidak menutup kemungkinan dapat membuat Waduk Jatiluhur dapat lebih terkenal. Selanjutnya dari wisata religi Makam Syech Baing Yusuf, dalam wisata ini sangat terasa faktor strategi word of mouth yang secara tidak langsung meningkatkan kunjungan para wisatawan karena jenis wisata ini biasanya disampaikan oleh guru-guru spiritual pada masing-masing kelompok.

6. Mengumpulkan Umpan Balik

Setelah mengirim pesan, pemasar harus meneliti dampknya pada pemirsa sasaran. Hal ini melibatkan pengajuan pertanyaan kepada anggota pemirsa sasaran apakah mereka mengingat pesan, berapa kali mereka melihat pesan tersebut, apa saja yang mereka ingat, apa yang mereka rasakan tentang pesan itu, dan sikap masa lalu dan masa kini terhadap produk tersebut (Kotler dan Armstrong, 2008 : 131)

Pengiriman pesan sudah dilakukan oleh Kabupaten Purwakarta dalam upayanya menjalankan strategi promosi, maka langkah selanjutnya adalah meneliti dampak nya terhadap pengunjung wisatawan dimulai dari pertanyaan apakah pernah melihat pesan 
promosi pariwisata Kabupaten Purwakarta. Hasil wawancara dilapangan dari lima pengunjung haya dua pengunjung yang pernah melihat pesan promosi, hal ini menunjukan bahwa masyarakat sendiri tidak seluruhnya terpapar oleh pesan yang selama ini disebarkan oleh pengelola wisata dan mengetahui objek wisata karena adanya strategi word of mouth dari orang-orang terdekat.

Selanjutnya para pengunjung mengingat pesan yang disampaikan melalui media sosial hal ini tentunya sejalan dengan Kabupaten Purwakarta yang memang lebih fokus menyebarkan informasi melalui media sosial. Seluruh pengunjung memiliki respon yang sama yaitu ingin datang ke objek-objek wisata yang lainnya setelah melihat pesan promosi dan setelah berkunjung langsung ke objek wisata di Kabupaten Purwakarta, respon yang lebih postif juga di nyatakan oleh semua pengunjung yang datang bahwa setelah berkunjung ke Kabupaten Purwakarta maka akan menyebarkan informasi seputar wisata di Purwakarta dengan orang-orang terdekat dan juga melalui media sosial, dari segi peluang ini lah yang harus dilihat secara jeli oleh Kabupaten Purwakarta dengan berusaha menyebarkan informasi secara lebihe efektif sehingga seluruh masyarakat dapat terpapar pesan promosi tersebut.

7. Penetapan Anggaran Promosi

Ada empat metode umum yang digunakan untuk menetapkan anggaran promosi, antara lain metode terjangkau, metide presentase penjualan, metode paritas kompetitif dan metode tujuan dan tugas (Kotler dan Armstrong, 2008: 132-134)

Kabupaten Purwakarta merupakan Kabupaten terkecil di Jawabarat dengan luas wilayah 971,7 $\mathrm{Km}^{2}$, tentunya memiliki keterbatasan di bidang APBD maka dari itu anggaran untuk promosi pun sejauh ini hanya menyesuaikan dari jangkauan dana tersebut seperti di tahun 2017 APBD Purwakarta hanya berjumlah $\mathrm{Rp}$ 2.402.888.790.039. maka dari itu penetapan anggaran promosi belum berdasarkan kebutuhan dari promosi wisata, oleh karena itu disimpulkan bahwa metode yang digunakan dalam penetapan anggaran promosi adalah metode terjangkau. Anggaran promosi yang belum menjadi prioritas tentunya metode ini memiliki kekurangan yaitu mengabaikan dampak promosi pada penjualan serta menempatkan promosi pada tempat terakhir di antara prioritas pembelanjaan. Melihat keterbatasan dana yang tersedia maka Kabupaten Purwakarta mengelola media-media yang tidak berbayar seperti media sosial dan juga pemanfaatan SDM, dengan cara mengundang seluruh siswa dan mahasiswa untuk mau ikut mempromosikan wisata Kabupaten Purwakarta melalui media sosial. 


\section{KESIMPULAN DAN SARAN}

\section{Kesimpulan}

Berdasarkan penelitian yang dilakukan oleh penulis, maka terdapat kesimpulan mengenai bagaimana strategi promosi pariwisata yang dilakukan oleh Kabupaten Purwakarta, yaitu :

Identifikasi sasaran yang dilakukan oleh Kabupaten Purwakarta adalah mengutamakan masyarakat Purwakarta sebagai target pengunjung pariwisata, namun berbeda dengan objek wisata yang sudah terkenal seperti Waduk Jatiluhur dan wisata religi Makam Syech Baing Yusuf yang sudah menjangkau masyarakat luar Purwakarta sebagai target pengunjungnya. Tujuan komunikasi yang dilakukan sudah mencakup menginformasikan, mempengaruhi serta mengingatkan hanya saja khusus pesan yang disampaikan oleh Dinas Pendidikan kepada MKKS mengenai Taman Surawisesa hanya untuk menginformasikan dan mengingatkan belum bertujuan mempengaruhi.

Rancangan pesan berdasarkan isi pesan menggunakan tema rasional dengan mengangkat keunggulan objek wisata, tema emosional yang mencerminkan kebanggaan pengunjung serta tema moral yang berusaha di sampaikan di sela-sela pesan promosi. struktur dan format pesan sudah sesuai. Pemelilihan media yang digunakan yaitu media cetak, media sosial, media reklame, media penyiaran, melakukan strategi word of mouth dan buzz marketing secara tidak langsung serta mengadakan berbagai event dan berusaha menciptakan suasana yang identik dengan karakter Kabupaten Purwakarta yaitu alam pedesaan dengan budaya sunda di dalamnya. Pemilihan sumber pesan berasal dari para pemimpin birokrasi serta tokoh Bupati Purwakarta Dedi Mulyadi. Umpan balik yang di dapatkan mengenai penerimaan pesan tidak terlalu baik karena tidak semua pengunjung pernah melihat pesan promosi yang disampaikan, hanya saja respon yang sangat positif yaitu seluruh pengunjung akan datang lagi dan mengunjungi objek wisata yang lainnya serta akan menyebarkan informasi positif mengenai objek wisata di Kabupaten Purwakarta melalui media sosial dan orangorang terdekat. Metode penetapan anggaran promosi menggunakan metode terjangkau sesuai dengan anggaran yang tersedia.

\section{Saran}

Setelah penulis melakukan penelitian di Kabupaten Purwakarta dan wawancara mendalam dengan narasumber dari pihak Dinas Pariwisata, Dinas Pendidikan serta Pengelola objek wisata Waduk Jatiluhur mengenai strategi promosi yang dilakukan, maka penulis hendak memberikan beberapa saran kepada Kabupaten Purwakarta, yaitu:

1. Kabupaten Purwakarta sebaiknya mengoptimalkan seluruh media bukan hanya media sosial melainkan media cetak yang bisa di fokuskan ke masalah 
pendistribusiannya. Mengoptimalkan media penyiaran lokal sehingga dapat menghemat biaya promosi, menambah media reklame sebagai media promosi bukan hanya saat adanya event-event tertentu.

2. Mulai melakukan perencanaan startegi word of mouth dan buzz marketing sebagai media promosi alternatif yang tidak mengeluarkan banyak biaya namun memiliki dampak yang efektif.

3. Dinas Pendidikan sebaiknya mulai menyampaikan promosi melalui media website dan media sosial milik Dinas Pendidikan sehingga tidak hanya mengandalkan promosi dari Dinas Pariwisata dan juga mulai untuk melakukan penyususunan pesan promosi yang lebih terencana sehingga tercapai segala aspek tujuan promosi.

4. Penerapan tema emosional dan juga tema moral sebaiknya mulai di rencanakan karena dapat dijadikan variasi isi pesan promosi yang lebih menarik banyak minat wisatawan.

\section{DAFTAR PUSTAKA}

Afrizal. (2014). Metode Penelitian Kualitatif. Jakarta: RajaGrafindo Persada

Ardianto, Elvinaro, dan Bambang Q. Anees. (2007). Filsafat Ilmu Komunikasi. Bandung: Simbiosa Rekatama Media

Bungin, Burhan. (2007). Penelitian Kualitatif: Komunikasi, Ekonomi, Kebijakan Publik, dan Ilmu Sosial Lainnya.
Jakarta: Kencana Prenada Media Group

Daryanto. (2011). Manajemen Pemasaran. Bandung: Satu Nusa

Fadil, Zaki dan Utama, Priyo. (2015). Teknik Marketing Itu Mudah. Yogyakarta: Second Hope

Hurriyati, Ratih. (2005). Bauran Pemaran dan Loyalitas Konsumen.Bandung:Alfabeta

Keegan, Warren J. 2002. Manajemen Pemasaran Global. Pretice Hall: New Jersey

Kotler, Phillip dan Gary, Armstrong. 2001. Prinsip-prinsip Pemasaran: Jilid 1,Edisi Kedelapan. Jakarta: Erlangga

Kotler, Philip and Kevin Lane Keller. 2012. Marketing Management 13. New Jersey: Pearson Prentice Hall, inc.

Leiper, Neil. 2004. Tourism Management. Australia: Person Hospitality Press

Mason, P. 2004. Tourism Impacts, Planning, and Management. London: Elvesier

Lupiyoadi, rambat.2014.Manajemen Pemasaran Jasa. Jakarta:Salemba Empat.

Nazir, Moh. 2005. Metode Penelitian. Bogor: Ghalia Indonesia.

Malau, Harman. 2017. Manajemen Pemasaran. Bandung: Alfabeta

Philip Kotler, Gary Armstrong 2008. PrinsipPrinsip Pemasaran Jilid 1 -12/E. Jakarta: Erlangga,

Prastowo, Andi. (2011). Memahami MetodeMetode Penelitian: Suatu Tinjauan Teoritis dan Praktis. Yogyakarta: ArRuzz Media

Samsuridjal,Kaelany.(1997).Peluang di Bidang Pariwisata. Mutiara Sumber Widya 
Satori,Djam'an dan Komariah, Aan. (2009).

Metodologi Penelitian Kualitatif

Bandung : Alfabeta

Silalahi. (2009). Metode Penelitian Sosial.

Bandung: Refika Aditama

Wardiyanta (2006) Metode Penelitian

Pariwisata, Yogyakarta: Andi

Yoeti, Oka A. 2013. Pemasaran Pariwisata.

Bandung: Angkasa

Yoeti, Oka A. 1996. Pengantar Pariwisata.

Bandung: Angkasa 